DEUİF LIII / 2021, ss. 89-109.

\title{
İbn Sînâ'da Sıddıkîn Delili: Tanrı Kanıtlaması
}

Fevzi YİĞİT*

ÖZ

Bu çalışmada İbn Sînâ'nın Tanrı ispatlaması konu edinilmiştir. İbn Sînâ, Zorunlu Varlık'tan Tanrı'ya, Tanrı'dan da âleme ulaşarak verdiği hükme "sıddıkların hükmü” adını verir. Çünkü sıddıklar, âlemden hareketle Tanrı'yı tasdik etmek yerine Tanrr'dan hareketle âlemi tasdik ederler. Konuyla ilgili diğer çalışmalardan farklı olarak bu çalışmada, Tanrı ispatlamasında aklın yanında vehmin de rol aldığı, sıddıklardan başka halkların da Tanrı'nın şahitliğine mazhar olduğu ileri sürülmüştür. İşte ezan ve kelime-i şehadet bunun bir ifadesidir. Halk; itikat yönünden Tanrı konusunda şaşkın ve kararsızken vehmin olumlu gücü sayesinde inancında net ve kararlllık içerisindedir. Bu yüzden Peygamberler halk için sadece söyledikleriyle değil varlıklarıyla da Tanrı'ya delil olmaktadır. Bu bağlamda ateist ve agnostiklerin Tanrı'nın mahiyetine yönelik karşı koyuşlarının makul ancak bir tür yetersizlik ve yine varllğın apriori bilgisinden gafil kalmalarından dolayı Tanrı'nın varlığını yadsımalarının güçlü bir yanılg1 olduğu söylenmiştir. Oysa İbn Sînâ'ya göre Tanrı, mahiyetinin olmaması sebebiyle zihinsel/rasyonel açıdan ispatlanamaz. Öte taraftan Tanrı, varllğının apaçılığı ve aklın da menşei olması itibariyle ispata bile konu olmayacak kadar açık bir varlıktır. Bu hükmü/burhanı, ontolojik delilinden farklı kılan özelliği “Tanrı vardır." önermesindeki "varlık” yükleminin özne pozisyonuna çekilmesi yani varllğın mahiyetin bir sıfatı olarak asla değerlendirilemeyeceğidir.

Anahtar Kelimeler: İslâm Felsefesi, İbn Sînâ, Sıddıkîn Delili, Varlık, Tanrı.

Avicenna's "Proof of the Truthful": Proof for the Existence of God

ABSTRACT
In the present article, I represent Avicenna's proof for the existence of God.
Ibn Sînâ calls the judgment he made by reaching God from the Necessary
Being and from God to the universe "the judgment of the faithful". For the
*
Dr. Ö ğr. Üyesi. Nevşehir Hacı Bektaş Universitesi Illahiyat Fakültesi, Islam
Felsefesi Anabilim Dalı Assistant Professor, Nevsehir Hac1 Bektas Veli University,
Faculty of Theology, Department of Islamic Philosophy. Nevsehir, Turkey
fevziyigit@nevsehir.edu.tr ORCID ID: https://orcid.org/0000-0001-9420-5186
Makalenin Hakemlere Gönderiliş Tarihi : $14 / 09 / 2020$
Makalenin Hakemlerden Geliş Tarihi : $17 / 11 / 2020$


Siddigs affirm the universe with reference to God, instead of affirming God with reference to the universe. Unlike other studies on the subject, in this study, it is mentioned that wabm also plays a positive role besides reason in the proof for the existence of God, and that is why folks do witness God's existence as well. The feature that distinguishes this judgment/demonstration from the ontological argument is that the predicate "existence" in the proposition "there is God" is drawn to the position of subject, that is, existence can never be considered as an attribute of quiddity. In this context, I also argue that the opposition of atheists and agnostics against to the nature of God is a reasonable but a kind of inadequacy, and it is a strong mistake that they deny the existence of God because they are unaware of the a priori knowledge of existence. According to Avicenna, God's existence cannot be proved rationally due to his lack of quiddity. On the other hand, God's existence is too obvious to be subject to demonstration, in terms of having a self-evident existence and being the origin of the reason.

Keywords: Islamic Philosophy, Avicenna, The Proof of the Truthful, Existence, God.

\section{GİRİ̧}

İbn Sînâ (ö. 428/1037), el-İşârât ve’t-Tenbîhât ta Tanri'nın varlığının ispatına dair "sıddıkların hükmü" adı verdiği yeni bir kanıt zikretti. Uzun uzadıya anlatmadığ1 bu kanıtı metafizik bilgiye sahip olan kişilere yani sıddıklara has kıldı. Bu makalede şu hususların altı çizilmektedir: Birincisi, bu delilde, varlık olması açısından varlık ilk hareket noktası olarak tayin edilmektedir. İkincisi, "varlık olması açısından varlıktan" Tanrı'ya, Tanrı'dan ise âlemin varlığına geçilmektedir. Üçüncüsü varlık hem aklın hem de vehmin yarg1 alanına girdiğinden halkların Tanrı'nın varlığını kolaylıkla kabul ettikleri görülmektedir ki bu durum Tanrı'dan âleme delil getirmenin bir örneğidir. Dördüncüsü, ateist ve agnostiklerin farklı Tanrı algılarından yani Tanrı'nın mahiyetinden hareketle Tanrı'nın varllğııı yadsımaları güçlü bir yanılgıdır.

Bu makalede şunlara işaret edilecektir: Zorunlu varlık kavramı, varlık-mahiyet bağlamında Tanrı'nın ispatlanıp ispatlanamayacağı, aklın ve vehmin bu ispattaki rolü, varllğın veya zorunluluğun Tanrı'ya ait bir yüklemi mi yoksa tersinin mi geçerli olduğu. Makalede Siddıkin kanıtının metafizik bir kanıt olup olmadığına, ontolojik delilden farkına ve varlığın teşkîkî yapısına dair işaretler vardır. Makalenin amacı ise -İbn Sînâ'nın 
sıddıkların hükmü fikrinden hareketle- Tanrı kanıtlaması yapılırken varlığın dış dünyadaki gerçekliğinin en önemli ve biricik temel dayanak noktası olduğunu göstermektir.

Aristoteles (ö. MÖ 323), metafiziğin konusunu mevcut olmas1 açısından mevcut olarak belirlemişken Tanrı hakkında hareket delilinden öteye gidememesi, meselenin ne kadar büyük bir güçlüğe sahip olduğunu göstermesi açısından önemlidir. Hareket delili eserden müessire giden İnnî burhan kategorisinde bir delildir. Buna göre Tanrı bütün varlıkla özdeşleştirilebilecek bir mevcut olmaktan ziyade diğer bütün mevcutlar içerisinde aşkın ve üstün bir konuma sahiptir. Aristoteles'in eksik bıraktığı Tanrı kanıtlamasını tamamlamak için metafizikçiler Zorunlu Varlık fikrinden hareketle Tanrı'ya ulaşmaya çalışmıştır. Buna göre bütün mevcutlar Zorunlu Varlık'tan sudûr etmekte ve onun zâtının lazımları olmaktadır. ${ }^{1}$ Metafiziğin asıl konusu varlık olmakla birlikte Tanr1 kanıtlamasının yapılacağı yer de metafiziktir. ${ }^{2}$ Ancak bu ikisinin karıştırılması durumunda bazı yanlış anlamalar ortaya çıkmaktadır. Ayrıca metafizik hem dikey ve yatay nedenleri hem de mutlak ile izafî olanı uzlaştırabilecek tek ilimdir. ${ }^{3}$ Buna göre Tanrı ispatlamaları, mantıksal olarak varlı̆̆ın tasnifine, bu tasnifin diş dünyaya uygulanışına ve dış dünyada varlığın inkâr edilemez gerçekliğine dayanmaktadır. ${ }^{4}$

\section{Ontolojik Delil}

İbn Sînâ gerek eğitimde gerekse bilginin elde edilmesinde basitten zora ve görünenden görünmeyene gidilmesini uygun görür. Buna göre metafizik, matematik ve fizik ilimleri içerisinde insanın kavrayışına en yakın olanı fizik ilmidir. ${ }^{5}$ Bununla birlikte umumun aksine insanın anlayış gücü arttıkça bu durum tersine dönmektedir. Filozof ve arifler, asıl

\footnotetext{
1 İbn Sînâ, et-Ta lạkât, nşr. Abdurrahman Bedevî (Beyrut: Dârü’l-İslâmiyye, ts.), 62.

2 İbn Sînâ, Metafizike, çev. Ekrem Demirli - Ömer Türker (İstanbul: Litera Yayıncilık, 2013), $1 / 4$.

3 Frithjof Schuon, İslâm ve Ezelî Hikmet, çev. Şahabeddin Yalçın (İstanbul: İz Yayınc1lik, 1998), 88.

4 Ömer Mahir Alper, “İbn Sînâ'da Tanrı'nın Kanıtlanması Sorunu: O Gerçekten Kelâmc1lardan Etkilendi mi?” İstanbul Üniversitesi İlabiyat Fakültesi Dergisi 7 (2003), 69.

5 İbn Sînâ, Dânişnâme-i Alẩ, çev. Murat Demirkol (İstanbul: Türkiye Yazma Eserler Kurumu Başkanlığı Yayınları, 2013), 138.
} 
anlaşılır olanın metafizik âlem, idraki güç olanın ise fiziki âlem olduğunu söylemektedir. İbn Sînâ'nın Tanrı ispatlaması da bir anlamda bu gerçeği ifade eder. Bugünkü modern fizik de bu görüşü doğrulamaktadır. İnsan maddeyi ve fiziki âlemi tanıdıkça şaşkınlığı artmakta ve onu ne kadar az bildiğinin farkına varmaktadır.

Ontolojik delilin iki formu vardır: Birincisi, zihindeki mükemmel varlık fikrinden dış dünyaya gidilir; bu durumda delil mantıki olur. İkincisinde, dış dünyadan hareketle Tanrı'ya gidilir; bu durumda delil metafiziksel olur. ${ }^{6}$ Hick'e göre var olmak olumlu bir nitelik olarak en mükemmel olana yüklenebilirken var olmamak olumsuz bir nitelik olarak en mükemmel olanla çelişir. Diğer taraftan varlık, insan zihninin bir ürünü olarak Tanrı'ya yüklenir ve dış dünyada gerçeklik sahibi bir yüklem olarak kabul edilmezse delil işlevini yitirir. ${ }^{7}$ Dil ve mantık açısından varlık, bir yüklemdir. Hâlbuki ontolojik açıdan varlık tek gerçekliktir. Zihinsel açıdan bütün mevcutlar varlık ve mahiyetten oluştur ve delil/burhan varlığı, tanım ise mahiyeti verir. Tanım cins ve ayrımlardan oluşur, burhan ise mutlak ve özel olarak meçhul olanın varllğını verir. ${ }^{8}$

Delil/Burhan, şeye zâtî bir araz verirken tanım ise şeyi var kılan zâtîleri verir. Örneğin burhan, üçgenin iç açılarının iki dik açıya eşit olduğunu verir. Bu anlam, üçgenin tanımının dışındadır. ${ }^{9}$ Ayrıca varlığı tanımın bir parçası ve sıfatı olarak görmek zaten onu zihinsel işlemden geçirmek demektir. Dolayısıyla ontolojik anlamda varlığın yüklem olmasından bahsetmek bu ikisini ayırmaya tam olarak gücümüzün yetmediğini gösterir.

Ontolojik delil şöyle ifade edilebilir: "Tanrı, tanımı gereği tam ve yetkindir. Tam ve yetkinlik için varlık gereklidir; öyleyse, Tanrı vardır." Kant'ın (ö. 1804) itirazını dillendiren birçok modern düşünür temelde varlığın yüklem olmadığını ve şeyin yetkinliğine katkı yapmadığını

6 Morewedge ve diğer Batılı yazarlar delilin üç ve dördüncü çeşidinden bahsetmektedirler. Aşağıda bununla ilgili bilgi verilecektir.

7 John Hick, "Tanrının Varlığının Delilleri”, çev. Şahin Efil, Inönü Üniversitesi Uluslararasi Sosyal Bilimler Dergisi 2/2 (2013), 82.

8 İbn Sînâ, Analitikler, çev. Ömer Türker (İstanbul: Litera Yayınc1lı, 2014), 313.

9 İbn Sînâ, Analitikler, 293. 
söylemiştir. Onlara göre ortada ontolojik bir delillendirme değil tanımsal bir doğruyu oluşturmak için kurulmuş önermelerden başka bir şey yoktur. Şu hâlde "Tanr1 vardır." önermesi olgusal bir ispata konu olamaz. ${ }^{10} \mathrm{Bu}$ görüşte olanların farkına varmadan yaptıkları şey, "Tanrı vardır." önermesinin gücünü kırmak için varlığın apaçık gerçekliği ve zihne yansıyan apriori bilgisini dışlamalarıdır. Doğru ifadesi "Varlık Tanrı'dır." olarak tasarlanmış olması varlığın birliğini ve en azından çelişik gibi görünse de çoklu birliğini geçersiz kılmaz.

Tanrı'nın varlığına zorunlu niteliğini eklemek O'na bir mahiyet belirlemek midir yoksa zaten var olan her şey zorunlu mudur? Eğer sorunun birinci kısmına "evet" cevabı verilirse; bu durumda, Tanrı'nın varlığ başka niteliklerine de neden olur ki bu da O'nun bir mahiyet sahip olması demektir. Eğer sorunun ikinci kısmına "evet" cevab1 verilirse bu durumda Tanrı, âlem vb. gibi ayrımların bir değeri kalmayacaktır. İbn Sînâ'nın konu ile ilgili tutumu Tanrı'nın bir mahiyetinin olamayacağ yönündedir. Dolayısıyla varlık, zorunluluğun menşeidir. Ancak Tanrı zâtı gereği zorunlu iken âlem ise zorunluluğu O'ndan alır.

Ontolojik delilin Batı'da Descartes'le (ö. 1650) birlikte teolojik bir delil hüviyetine bürünmeye başlandığı söylenebilir. $\mathrm{O}$, şöyle demektedir: "Bende mükemmel bir Tanr1 kavramı vardır; o halde Tanr1 mevcuttur." 12 Buna yöneltilen eleştiriler, genellikle varllğın bir yüklem olup olamayacağı yönündedir. ${ }^{13}$ İbn Sînâ'nın bu tür bir Tanrı ispatlamasıyla alakası olmadığı söylenmelidir. İbn Sînâ'nın el-Evvel'in ispatından anladığ1 şey, el-Evvel'in varlık sebebini araştırmak değil şuan mevcut olan bütün mevcutların onun varllğına bağlı olduğunu ortaya koymaktır. ${ }^{14}$

Zorunlu Varlık fikrinin mantıksal zorunluluğa dayanmadığ1 genel kabule mazharken Aziz Anselm (ö. 1109) ve Thomas Aquinas'ın (ö.

10 Mehmet Sait Reçber, “Tanrı'nın Varlığının Delilleri”, Din Felsefesi, ed. Recep Kılıç Mehmet Sait Reçber (Ankara: Grafiker Yayınları, 2014), 125-127.

11 İhlas Sûresinin ilk ayetini bu yönde yorumlayanlar olmuştur.

12 Descartes, Felsefenin İlkeleri, çev. Mesut Akın (İstanbul: Say Yayınları, 1995), 64.

13 Mehmet Dağ, "Ontolojik Delil ve Çı1kmazları", Ankara Üniversitesi Ilaahiyat Fakültesi Dergisi 23 (1979), 290.

14 İlhan Kutluer, İbn Sina Ontolojisinde Zorunlu Varlı (İstanbul: İz Yayıncilik, 2013), 129. 
1274) ontolojik delil yorumlarının da bir tür olgusal zorunluluğa yani ilk ve kendiliğinden varlık fikrine dayandığ söylenmiştir. ${ }^{15} \mathrm{Bu}$ yorumlar kabul edilirse ontolojik delil Sıddıkîn deliline yaklaşmaktadır. Ancak İbn Sînâ'nın delilini, Tanrı'da varlık ve mahiyet ayrımı yapan Anselm, Descartes ve Kant gibi düşünürlerin delillerine nispet etmek pek doğru gözükmemektedir. ${ }^{16}$ Metafizik/ontolojik delil üzerinde yaşanan kafa karışıklığının nedenlerinden birisi "Tanrı vardır." ve "Varlık vardır." cümlelerinin birbirine karıştırılmasıdır. Diğeri ise Tanrı kavramı üzerinde yaşanan ihtilaflardır. ${ }^{17}$

Morewedge'nin ontolojik delili incelediği makalesinden anlaşılan Daniel De Haan'ın da ifade ettiği gibi- o, İbn Sînâ'nın metafiziksel ayrımlarını Tanrı ispatlaması şeklinde anlamışırı. ${ }^{18}$ Bu yüzden İbn Sînâ'yı ontolojik delilin üç formunda da başarısız olarak değerlendirmiştir. ${ }^{19}$ Bununla birlikte İbn Sînâ'nın Tanrı kavramından hareketle bir ispata gitmediği yönündeki çıkarımı yerindedir. Morewedge'nin bu tutumu delilin dördüncü formunda bahsedilmesi ihtiyacını doğurmuştur.

Dördüncü delil yazarlarına göre, İbn Sînâ’nın varllğı kategorilerin üstünde tutması zorunlu varlıkla Tanrı arasında kurulan bağlantının niteliksel ve kategorik olmamasını sağlar ve bu da birçok eleştirinin bertaraf edilmesi imkânını doğurur. Lakin bu yazarlar metafizik bilginin mahiyetini ruhani bir bilgi olarak değerlendirerek sanki delillendirmeden kullanılan mevcutların sadece soyut varliklar ve elde edilen bilgilerin de sezgisel bilgiler olduğunu ima ederek yanılmışlardır. Ancak Henri Corbin'in maddenin kendisinde bile akli bir zemin olduğu yönündeki

15 Hick, “Tanrının Varlığının Delilleri”, 85-86.

16 Engin Erdem, Varliktan Tanriya İbn Sînânmn Metafizik Delili (İstanbul: Endülüs Yayınlar1, ts.), 284.

17 René Guénon, Doğu Düşüncesi, çev. L. Fevzi Topaçoğlu (İstanbul: İz Yayıncılık, 2004), 102.

18 Parviz Morewedge, "İbn Sina, N. Malcom ve Ontolojik Delil", çev. Mehmet Ata Az, Din Felsefesi Açısından Meşşẩ Gelen-Ek-i IV, ed. Recep Alpyağıl (İstanbul: İz Yayıncilık, 2019), 394 vd.

19 Parviz Morewedge, "İbn Sina Metafiziğinde Ontolojik Argümanın Üçüncü Versiyonu", çev. Yasin Ramazan Başaran, Din Felsefesi Açısından Meşşẫ Gelen-Ek-i IV, ed. Recep Alpyağıl (İstanbul: İz Yayıncılık, 2019), 428. 
tespitini zikretmeleri önemlidir. ${ }^{20}$ Mayer ise varlık mahiyet ayrımının Tanrı'ya uygulanamayacağı ve bunun Tanrı'nın aşkın yönüne vurgu yapmak olduğunu ifade ederken meseleden oldukça uzaklaşmış görünmektedir. ${ }^{21}$ Geleneksel İslam felsefesi araştırmasını andıran başarılı incelemesiyle Daniel D. Haan konuyla ilgili araştırma yapanların kavram kargaşasına düştüğünü ve İbn Sînâ'nın kendi metinlerinin merkeze alınmaması dolayısıyla da araştırmacıların hata yaptığını dile getirmiştir. Ona göre Metafizice 6 ve 7'de İbn Sînâ metafizik yapmakta Tanr1 ispatlamasında bulunmamaktadır. Tanrı ispatlaması ise Metafizik 8'de yapılmaktadır. Hâsılı bağlamından koparılınca İbn Sînâ'nın delilleri kozmolojik ya da ontolojik görünüme bürünmekte ve hatalı değerlendirmelere neden olmaktadır. ${ }^{22}$

\section{Tanrı'nın Varlığı Ve Siddıkîn Delili}

"Mevcut olmak bakımından mevcut" araştırmasıyla "varlık olmak bakımından varlık" araştırması arasında küçük fakat önemli bir fark olduğunu söyleyebiliriz. Çünkü birincisinin zihin aracillğıyla cevher temelli bir inceleme, ikincisinin ise akıl aracıllğıyla varlığın kendisi temelli bir inceleme olduğu söylenebilir. Buradan hareketle İbn Sînâ'nın Issârât ta "varlık olmak bakımından varlık" araştırmasına yöneldiği görülmektedir. Bu haseple o, $\dot{I}_{s} \hat{a} r a \hat{t} \mathcal{t}_{1}$ n ilgili pasajında sıddıkların hükmü diye tanıttı̆̆ delilinde el-Evvel'i ispat etmek için herhangi bir beyan ve açıklamaya ihtiyaç olmadığını sadece varlığın kendisinin derinlemesine düşünülmesinin yeterli olduğunu bildirir. Ona göre bu delilde, âlemden Tanrı'ya ve eserden müessire gidildiği için değil bizâtihi varlık esas aldığı için o, diğer delillerden daha üstün ve güvenilirdir. Delilin özü ikili bir zihinsel faaliyeti içerir. Birincisinde varllğın hallerinden varllğın kendisine yani varlık olması açısından varlığa gidilir. İkincisinde varlık olması

20 Faruq Abdullah - Steven A. Johnson, “İbn Sina Metafiziğinde Dördüncü Ontolojik Delil”, çev. Zeynep Baktemur, Din Felsefesi Açısından Meşşâ̂̀ Gelen-Ek-i IV, ed. Recep Alpyağıl (İstanbul: İz Yayıncılık, 2019), 432-435.

21 Toby Mayer, “İbn Sîn'nın 'Burhânu’s-Sıddikîn'i”, çev. Temel Yeşilyurt, İnönü Üniversitesi İlahiyat Fakültesi Dergisi 8 (2003), 275-276.

22 Daniel D. De Haan, “İbn Sina, Tanrı'nın Varlığını Nerede İspatlıyor?”, çev. Sultan Turan, Din Felsefesi Açısından Meşşẩ Gelen-Ek-i IV, ed. Recep Alpyağ1l (İstanbul: İz Yayıncilik, 2019), 469. 
bakımından varlıktan Tanrı'ya, Tanrı'dan ise tekrar mevcudata gidilir. Bunun diğer ifadesi Tanrı'nın mevcutlar üzerine şahit olmasıdır. ${ }^{23}$

Sıddıkîn delilinin özü, varlık dışında el-Evvel'e delil getirilemeyeceğidir. Bu durum varlık sahasının bir yansıması olan mantık için de geçerlidir. Bununla birlikte mantıksal açıdan el-Evvel'e burhan getirilememesiyle ontolojik açıdan getirilememesi iki yönden ayrı durumlardır. Birincisine göre İlk’in cins ve faslı olmadığı için O'na burhan getirilemez. Şöyle ki zihin, diş dünyadaki mevcutları belirli bir sıraya ve düzene sokar. Buna göre el-Evvel diğer mevcutlar sınıfinda olmadığı için bu sinıflamaya dâhil edemez. İkincisine göre O’nun varlığ1 dışında başka bir varlıktan bahsedilemeyeceği için O'na burhan getirilemez. Varlığın diğer mevcutlardan nefyedilmesi onların mevcut olmadığ1 anlamına gelmez, tam aksine varlıklarının kendilerine ait olmadığı anlamına gelir. Yani varlık herhangi bir mevcudun sahiplenip onu diğerlerinden dişlayacağ1 zâtî bir nitelik değildir tam aksine varlık herkesin ve her şeyin öznesidir. ${ }^{24}$

İbn Sînâ'ya göre Zorunlu Varlık yegâne haktır. Onun haktan kastı mutlak anlamda dış dünyada sürekli olarak var olmasıdır. Gerçekliğin şartı ise hakkında konuşulan ile dış dünyada olanın mutabık olmasıdır. Zorunlu Varlık zâtı gereği asıl gerçekliktir; mümkün varlık ise kendinde batıl, zorunlu ile gerçeklik kazanandır. ${ }^{25}$ Dolayısıyla varlık kazanan her şey, mutlaka bir yönden onun sebebiyle zorunlu hale gelmiştir. ${ }^{26}$ Şu hâlde Zorunlu Varlık'ın bir nedeni yani varlığının dayandığı başka bir varlık yoktur. ${ }^{27}$ "O mevcuttur." denilince bunun manası zâtından dolayı mevcut olduğudur, kendisinin dişında başka bir sebeple değil. Yani onun

23 İbn Sînâ, Issaretler ve Tembibler, çev. Ali Durusoy - Ekrem Demirli (İstanbul: Türkiye Yazma Eserler Kurumu Başkanlığ1, 2014), 474; Kutbüddin Râzî, Şerḥül-işârât vettenbihât (Kum: Neşrü'l-belâga, 1435), 3/67.

24 İbn Sînâ. Metafizike, 2/92.

25 İbn Sînâ. Metafizike, $1 / 46$.

26 İbn Sînâ. Metafizike, 2/105.

27 İbn Sînâ, el-Mebde've'l-me'ad (Tahran: İntişârât, 1998), 33. 
mevcudiyeti için aracı başka bir duruma ihtiyaç yoktur. Diğer mevcutlar ise aracıya ihtiyaç duyar. ${ }^{28}$

Zihnin dış dünyadan elde ettiği mahiyetlere gelince aslında lazım ve arazlarıyla birlikte varlığın taayyünü ve hakikatine bağlı olan şeylerdir. Bunlar dış dünyada varlığın hakikatinde bir çoğaltıma neden olmaz aksine bunlara varllğın taayyünü için ihtiyaç duyulur. ${ }^{29}$ İbn Sînâ'nın 'Zorunlu Varlık'ın, mahiyetinin olması ve varlığın zorunluluğunun bu mahiyetin gereği olması mümkün değildir." 30 sözünü "mahiyetlerin Zorunlu Varlık dışında kendilerine ait varlıkları vardır" şeklinde anlamak çok yanıltıcıdır. Çünkü diğer mevcutlar, Zorunlu Varlık'ın varlığılla mevcut olmakta ancak mevcudiyetlerine mahiyetlerinin varlığa bürünmesiyle ulaşmaktadırlar.

Zorunlu Varlık dışında her şeyde varlık, kendi mahiyetine dâhil değildir. Zihin bu şeyin varlı̆̆ını dışarıdan kendisine ulaşan bir öge olarak değerlendirir. Yani şeyin şeyliğiyle varlı̆̆1 arasında bir gereklilik bağ1 tesis etmez. Şu hâlde diş dünya zorunlu olarak ne varsa zâtı yönünden zorunlu olması, başka bir ifadeyle bilfiil varllğının olması gerekir. Zihinsel anlamda ve mutlak manada varlık -yani mastar anlaminda varlık- onun varlığının lazımlarından olmak durumundadır. ${ }^{31}$

Kısacası İbn Sînâ gerçekliği ve doğruluğu, varlı̆̆ı kendi zâtından olan Zorunlu Varlık'a atfeder. Onun dışında ne varsa batıldır. Zorunlu Varlık dışında bir varlık yoktur ki hak olsun ve kendisine şahitlik etsin. $O$, ancak zâtıyla bilinir. Bu durumla ilgili olarak o, "Allah kendisinden başka ilah olmadığına tanıktır." 32 âyetini dile getirir. ${ }^{33}$

28 İbn Sînâ, el-Mübâhasât, thk. Muhsin Bidarfer (Tahran: Müessese-i Pejûheşha-y1 Hikmet ve Felsefe-i İran, 1396), 300.

29 İbn Sînâ, el-Mübâhasât, 220.

30 İbn Sînâ. Metafizike, 2/89.

31 İbn Sînâ. et-Talıkât, 70.

32 Kur'ân-ı Kerîm Meâli, çev. Halil Altuntaş-Muzaffer Şahin (Ankara: Diyanet İşleri Başkanlığı Yayınları, 2010), el, Âl-i İmrân 3/18.

33 İbn Sînâ. et-Tallạât, 70. 
Zorunlu Varlık'1 diğer mevcutların zâtları gibi zât sahibi olması yönünden değerlendirmek doğru değildir. ${ }^{34}$ İbn Sînâ Isşarât ta varlığ kendisinden gelen ile varlığı başkasından alanın zâtının kavranmasının farklı olduğunu, birincisinin zâtının kavranması için varlığın kavranmasının yeterli olduğu, ikincisinde ise varlığın o şeyin zât1/mahiyeti ve zâtının lazımı olmadığı bu yüzden onu kavramak için varlığa ihtiyaç duyulmadığını söyler. ${ }^{35}$ İbn Sînâ'nın dile getirdiği bu kural, epistemolojik ve mantıksal bir ayrımı ifade eder. Buna göre bazı mahiyetlerin dış dünyada şahısları vardır, bazılarının ise yoktur. Olmayanları kavramak için var olmalarına ihtiyaç duyulmaz. Ve yine varlık dışındaki bütün mahiyetlerin zihin ürünü olduğunu söylemek gerekir. Çünkü mahiyetlerin kendilerine ait varlıkları olduğu kabul edilmesi durumunda, telafisi güç çokluk fikri ve mevcutların birbirine yüklemlenememesiyle karşı karşıya kalınır. Burada iki ana tutum vardır: Ya dış dünya ideal seviyede zihnin bir ürünü olarak değerlendirilecek ve Zorunlu Varlık kendinde salt bir hakikat olarak kabul edilecektir ya da diş dünya, salt gerçekliği yönünden Zorunlu Varlik'a izafe edilecek ve böylece bir tür realizme ulaşılacaktır. Bu realizme göre, varlığ1 yönünden âlem bilinebilir olurken mahiyeti yönünden bilinemez, muğlak ve müphem bir karaktere sahip olacaktır.

Dış dünyadaki gerçeklik ve asalet varlığa aittir. Zihin ise dış dünyadan hareketle mahiyetleri teşkil ettiği anda artık onları varlıklarına ihtiyaç duymaksızın tasavvur eder. Bu durumdan hareketle insan, dış dünyada mahiyetlerin kendileri sayesinde bulundukları ve varlığın bunlara bir araz gibi iliştiğini düşünür. İbn Sînâ'nın da böyle düşündüğü söylenemez. Çünkü varllğıı mahiyetten ayrışması veya ona katılması mahiyetler üzerinden gerçekleşmez. Yani varlık mahiyetin bir parçası değildir. Çünkü varlık bütün mevcutların, dış dünyadaki özlerin ve gerçeklik sahibi her şeyin kendisidir. ${ }^{36}$ Ancak buradan hareketle "varlık, mahiyetten hem zihinde hem de hariçte ayrıdır." ${ }^{37}$ gibi bir görüş ileri

34 Ali Ebrahimzadeh, "İbn Sînâ'da Zorunlu Varlığın Mahiyeti Meselesi”, Dini Arastirmalar 15/41 (2012), 160.

35 İbn Sînâ, İsaretler ve Tembibler, 466.

36 İbn Sînâ, İsaretler ve Tembibler, 468.

37 H. Ömer Özden, "İbn-i Sina ve Descartes'in Varlık Anlayışları Bakımından Karşılaştırılması", Felsefe Dünyası 16 (1995), 77. 
sürmek varlığın karşısına başka bir varlık koymak anlamına gelir ki bu da İbn Sînâ'nın kastı olmasa gerek.

İbn Sînâ'nın Zorunlu Varlık/hüviyet ${ }^{38}$ ile Tanrı arasında bir tür ayrıma gittiği söylenmelidir. Zaten bu ayrım gerçekleşmeden metafizikten bahsetmek mümkün gözükmemektedir. Şöyle ki varlık bilgisi bedîhi ve apriori iken Tanrı'nın varlığı ne kendiliğinden açıktır ne de açıklanması umutsuz bir vakadır. Yani Tanrı hakkında delile ihtiyaç duyulurken varlık hakkında delile ihtiyaç duyulmaz. Tanrı iki yönden incelenebilir: varlı̆̆ı ve sıfatlar1. ${ }^{39}$ Bütün varlıklar gibi Tanrı, varlığ1 açısından bedîhi ve apriori iken "mahiyeti varllğ1 olarak kabul edilse bile" mahiyete bürünmüş ve diğer mevcutlar karşısında konumlanmış hüviyet sahibi bir mevcut olması açısından yani sıfatları yönünden bedîhi ve apriori değildir. Şu hâlde Sıddıkîn delili Tanrı'yı varlığı yönünden ispatlamakta ve onu varlık olması açısından varlığın peşine eklemektedir. Başka bir ifadeyle Zorunlu Varlık ispatı yapılsa bile bu, burhan boyutunda varlığın dış dünyadaki apaçık gerçekliği ve bedîhi bilgisi temelinde yapılmakta buradan zihinsel ve mantıki boyuta geçilmektedir. Bu durumda duyusal, mücerret ve zihnî olarak varlık namına ne varsa Zorunlu Varlık, onların hepsinin üzerine şahit getirilmektedir. Ancak avamın bedîhi ve apriori bilgilerin idrakine varması ve illetten malule ulaşması mümkün olmamaktadır. ${ }^{40}$ Burada bir yanlış anlamaya mahal vermemek için hatırlatmak gerekir ki İbn Sînâ, zihinsel anlamda Zorunlu Varlik fikrinden hareket ederek bunu yapmamakta bilakis dış dünyadaki Zorunlu Varlık gerçeğinden hareket etmektedir.

İbn Sînâ'ya göre, halklar Tanr1 tasavvuruna peygamberler vasıtasıyla ulaşır. Bu tasavvurun temelinde Tanrı'nın bir ve eşsiz olduğu vardır. Âlemin dışında veya içinde bulunmayan bir Tanrı'yı tasdik etme sorumluluğuyla karşılaşan halk, derin bir sorunla karşı karşıyadır. Yetenekli çok az insan dışında insanlar genelde Tanrı konusunda kör bir iman, yetersizlik, ilgisizlik, şaşkınlık ya da inkâr içerisindedir. Bu

38 İbn Sînâ, İhlâs Sûresi Tefsiri, çev. Ahmet Hamdi Akseki, haz. Ahmet Faruk Güney (Ankara: Diyanet İşleri Başkanlığı Yayınları, 2019), 18-20.

39 İbn Sînâ, Metafi ìik, 1/ 4; Murat Demirkol, Tûsı̂nin İbn Sina Savunması (Ankara: Fecr Yayınlar1, 2010), 140.

40 İbn Sînâ, Metafizike, 1/19; Engin Erdem, "İbn Sînâ’nın Metafizik Delili", Ankara Üniversitesi İlahiyat Fakültesi Dergisi 52/1 (2011), 113. 
durumda peygamberin sembol ve benzetmelerle hakikatin temsillerini halka iletmesi gerekir. Halka yeter ölçüde Tanrı'nın eşi ve benzeri olmadığını anlatmalı ve ahiret hayatını hayallerine yaklaştırabilmedir. ${ }^{41}$

Hakikatinin bilinmesi yönünden faaliyette bulunan zihnin Tanrı'nın sıfatlarını ya olumsuzlamaya yönelik (tenzihi) sıfatlar ya da olumlamaya yönelik zâtî sıfatlar olarak değerlendirdiği söylenebilir. ${ }^{42}$ Zâtî sıfatlar, ontolojik anlamda bütün her şeyin kökeni ve sahibi olmayı ifade ederken ontolojik açılım ve yayılımın sonucu olan sıfatlar Tanrı'ya ancak dolaylı olarak atfedilebilir. Bunun diğer anlamı bunların Tanrı'dan tenzih edilmesidir. Olumlama da varlık yönündendir. Çünkü bütün olumlu nitelikler varlığın bir ürünü ve ona bağlı durumlardır. Şu hâlde Tanrı ile âlem arasında mahiyet yönünden bir benzerlik ve ortaklık olamaz. Başka bir ifadeyle her şey O'ndandır fakat onlar O'na ortak değildir. O, her şeyin ilkesidir ama $O$, kendisinden sudûr edenlerden biriyle özdeşleştirilemez. ${ }^{43}$ Kısacası İbn Sînâ'ya göre âlem Tanrı'dandır ancak Tanrı değildir. Bu panteist veya pananteist ideolojinin idrakinin fevkinde metafizik bir tavırdır. Hâlbuki diğerleri teolojik veya ideolojik bir tavır alıştır.

İbn Sînâ'nın anlatımlarında Tanrı'nın sıfatlarını ifade edecek en temel ilkeler şu şekilde belirlenmiş olmaktadır: zorunluluk, nedensizlik, teklik, birlik/basitlik ve etkinlik. Etkinlikten kastedilen O'nun ilim ve aklın ta kendisi olmasıdır. ${ }^{44}$ Zihin ve vehmin varlık, Tanrı ve sıfatları hakkında zorunlu hükümler verdiği ortadadır. Vehim, bir yeti olarak, beynin orta boşluğunun sonunda yer alır ve duyulurlardan duyulur olmayan anlamları çıkarır. Bunları diğer duyuların alg1laması mümkün değildir. Kısacası vehim öznenin nesneden kendisi için en uygun anlamı elde ettiği yetidir. ${ }^{45}$ Vehim sadece görünür nesnelerle sınırlı kalmaz, bazen

41 İbn Sînâ, Metafizike, 2/189.

42 İbn Sînâ, Arş Risalesi, çev. Enver Uysal, Uludă̆ Üniversitesi İlabiyat Fakültesi Dergisi 9/9 (2000), 646.

43 İbn Sînâ, Metafizike, 2/99.

44 Ömer Bozkurt, “İbn Sînâ'nın Tanrı Anlayışının Dayandığı Temel İlkeler”, Diyanet İlmî Dergi 50/1 (2014), 69-70.

45 Ahmet Kamil Cihan, İbn Sina ve Gazali'de Bilgi Problemi (İstanbul: İnsan Yayınları, 1998), 51. 
Tanr1 gibi soyut veya yarı soyut varlıklar hakkında hüküm verir. Bunu yaparken onları kendince görünür kılar. Örneğin vehmin etkisiyle nefis, mekânda olmadığından işaret edilemeyen varlıkların yokluğuna hükmedebilir. Hâsılı vehim hükümlerini duyulur tikellerle sınırlamalıdır. Çünkü o, mevcutların hakikatlerini değil varlıklarını bilmektedir. ${ }^{46}$

İbnü'l-Arabî’ye (ö. 638/1240) göre vehim, gerçekte epistemolojik açıdan zihinle karşılaştırılamayacak ölçüde zayıf olmakla birlikte bir yönden zihinden daha güçlü ve daha üstündür. ${ }^{47}$ İşte burası aklın hata yaptığ1, yanıldığ 1 ve yetersiz kaldığına dair söylemlerin ortaya çıtı̆̆ 1 noktadır. Şöyle ki Tanrı'nın varlığını bilmekte akıl ve vehim ortaklık içerisindedir. Lakin mahiyetin bilinmesi ve apaçık delillerin getirilmesi için akla/zihne başvurmak gerekir. Akıl Tanrı'nın neliği ve hakikati hakkında hükmetmekte ve zorunluluğa ulaşmaktayken vehim ise Tanrı'nın varlı̆̆ını görünürler içerisinde bulmaktadır. Halkın ve vehim gücü aklına baskın bireylerin akla/zihne karşı mesafeli davranmalarının sebebi de budur. Ateist vb. inkârc1 gruplar da bunlara dâhil edilebilir. Çünkü onların da Tanrı'nın mahiyetini akıllarıyla kavramaya çalıştıkları ve sonrasında elde ettikleri mahiyeti beğenmeyerek vehimleriyle Tanrı'nın varlığını reddettikleri görülmektedir. Çünkü vehim olumlu ve olumsuz hüküm verirken mümkün ve aynı zemine dayanmaktadır. Vehmi bu durumdan kurtarabilecek şey aklın ontolojik yönde çalışmasına izin vermektir. Sadece zihin seviyesinde akla işaret etmek onun analiz ve sentez yapan yönüne işaret etmektir. Keza metafizikçilere göre akıl özünde hem varlık hem bilgidir.

İbn Sînâ'nın vehmin sadece inkâr yönünde aklı baskılayan zorunlu hükümler vermediği tam aksine olumlu yönde hükümler de verdiğini kabul ettiği söylenebilir. Belki de Sıddıkîn delili birey ve halk açısından vehmin bu olumlu yönüne dayanmakta; filozof ise bunun üstüne aklın şahitliğini eklemektedir. İbn Sînâ bu yorumun benzerini Analatikler'de tahayyül hakkında yapılmaktadır. Buna göre tahayyül vehmin benzerini yaptığından kıyasın yerini almaktadır. Yani halkın tasdiki tahayyül vasitasıyla gerçekleşmektedir. ${ }^{48}$

46 İbn Sînâ, Analitikler, 33.

47 İbnü'l-Arabî, Fusûsü'l-Hikem, çev. Nuri Gencosman (İstanbul: MEB Yayınları, 1992), 264.

48 İbn Sînâ, Analitikler, 32 . 
Sıddıkîn delili Kur'ân'da sürekli tekrarlanan "Rabbin her şeye şahit olması" cümlesine dayanmaktadır. Buna göre hayvanlar, bitkiler ve cansızlar da bu şehadetin mazharlarıdır. Ancak bunun zihinsel idraki sadece insanda gerçekleşmekte ve doğal olarak bunu sadece insan problematik yapmaktadır. İşte sıddıklar burada devreye girmekte tasdiklerini yani zihinsel idraklerini ve ispatlarını bu yönde yani Tanr'nın her şeye şahit olması yönünde yapmaktadırlar. Bu duruma el-Fussilet 53. âyette işaret edilmekte ve ikili bir delillendirmeden bahsedilmektedir. Birincisinde evrenden ve insanin kendi nefsinden Tanrı'ya gidilmektedir. İkincisinde ise Tanrı'dan evrene gidilmektedir. İşte bu ikincisine İbn Sînâ tarafından "sıddıkların hükmü" ismi verilmektedir."

Anlaşılan "varlık olması açısından varlı̆̆ı" ve varlığı açısından Tanrı'yı saf akıl ve bir açıdan da vehim bilir. Vehim bu konuda isabet edebilir de edemeyebilir de. Ama vehmin tümel mevzularda aklın ve zihnin gerisinde kalıp hata ettiğinde şüphe yoktur. Şu hâlde Sıddıkîn burhanı birincil olarak peygamber, imam, filozof, arif filozoflar vb. gibi seçkin kimselere, ikincil olarak da halka aittir. Burada halkı oluşturan bireyler yanında halkın tümünün dikkate alınması gerekir. ${ }^{50}$ Özetle Tanrı bilinmesi yönünden varllğı ve Tanrılloğ1 cihetleriyle ayr1 ayr1 değerlendirilebilir. Varlı̆̆1 cihetiyle Tanrı, apriori varlık bilgisine tâbidir. Buradaki zorluk bu bilginin zihinsel idraki ve ifade edilebilmesinde saklıdır. Mahiyeti cihetiyle Tanrı aposteriori, analitik ve sentetik bilgiye tâbidir. Buradaki zorluk hakikati bulmakta yani farklı Tanrı tanım ve tasvirlerinin içerisinde en doğrusunu yakalamakta saklıdır. Her iki sahanın öznellik ve nesnellik yönü vardır. Ontolojik sezinleme ve huzurî bilgi açısından birincisi nesnel iken tümellere ulaşılıp herkesin anlayacağı ilmi seviye açısından ikincisi nesneldir.

Fahreddin er-Râzî (ö. 606/1210), İşââat şerhinde İbn Sînâ'nın hudûs ve imkân delillerinden farklı olarak varlığın halini itibara alarak Tanrı'dan evrene doğru ilerleyen bir yöntem uyguladığını belirtir. Şu hâlde varlığın zorunluluğu esasınca Tanrı'nın da zorunlu ve tek olması

49 İbn Sînâ, İsaretler ve Tembibler, 474.

50 Tolstoy, Tanrı inancına halkın Tanrı'ya inancı vasıtasıyla ulaştığını söyler. Ona göre evrende insan yığınları kadar Tanrısal başka bir şey olamaz. Tolstoy, İtiraflarm, çev. Orhan Yetkin (İstanbul: Kaknüs Yayınları, 1999), 77-80. 
gerekir. Hâlbuki bu durumda âlemin varlığını izah etmek güçleşir. Çünkü ya Tanrı'nın âlem olması ya da âlemin Tanrı olması gerekir. ${ }^{51}$ Nasîrüddin Tûsînin (ö. 672/1274) bu değerlendirmeye dair bir yorumda bulunmadığını görmekteyiz. Cevap vermemesinin muhtemel nedeni Râzî’nin bu delili imkân deliliyle karıştırdığını düşünmüş olması olabilir.

Kanaatimizce bu delili orijinal anlamda yorumlayan iki isimden bahsedilebilir. Bunlardan İbnü'l-Arabî, İslâm düşünce tarihinin en özgün düşünürlerinin başında gelir. Ona göre Tanr1, kendisi nedeniyle zorunluyken âlem onun sayesinde zorunludur. ${ }^{52}$ Tannr'nın varllğ̆1 mahiyeti demektir. ${ }^{53}$ Tanrı'nın zuhuru kendiliğindendir ve bu yönden âleme ihtiyaç duymaz. Şu hâlde böyle bir varlı̆̆ın gerçek ispatı âlem üzerinden değil kendisi üzerinden yapılabilir. Dahası O'ndan başka bir varlık yoktur ki onun üzerinden O'na ulaşılabilsin. ${ }^{54}$

İkincisi Molla Sadrâ’dır (ö. 1050/1641) ki o, bu delili güçlendirirken varlığın mahiyete karşı asaletine vurgu yapar; "varlığın teşkîkî ve mertebeli yapısı" fikrini delile katar. Ve yine malulün illete karşı bağımlı ve bağlantılı olduğunu dile getirir. ${ }^{55}$ Şöyle ki, dış dünyanın gerçekliği apaçıktır. Bu madde dolayısıyla bir apaçıklık değil varlıksal bir apaçıklıktır. Mahiyet sahibi bütün mevcutlarda asıl olan şey varlıktır. Dış dünyadan çıkartılabileceği gibi tek olan varlık farklı mertebelere sahiptir. Yani varlığın yetkinlik, hamlık, güçlülük, zayıflık vb. yönden farklılaştı̆̆ı görülür. Şu hâlde en üst mertebede bulunan varlığın ilk, varlığ1 en mükemmel, mutlak, sonsuz, en tam ve zorunlu olması gerekir. ${ }^{56}$

51 Fahreddin er-Râzî, Şerbü'l-İsârât ve't-tenbîhât: felsefe, tabiiyyât, ilabiyyât ve irfan, thk. Ali Riza Necefzade (Tahran: Encümen-i Asar ve Mefahir-i Ferhengi, 2005/1384), $1 / 383$.

52 İbnü'l-Arabî, Fütûhât-ı Mekkeiyye, çev. Ekrem Demirli (İstanbul: Litera Yayıncılık, 2011), 16/59.

53 İbnü'l-Arabî, Fütûhât-ı Mekkkiyye, 14/353.

54 İbnü'l-Arabî, Fütûhât-ı Mekkkiyye, 11/353.

55 Muhammed Tâkî Misbâh Yezdî, el-Menhecü'l-cedîd fi ta'limi'l-felsefe, nşr. Muhammed Abdü'l Münim el-Hakanî (Beyrut: Dârü't Teârifi li'l-Matbûât, 2008), 2/366.

56 Molla Sadrâ, el-Hikmetü'l-müte'âliye fî esfâri'l-erba'a. (Beyrut: Dâru İhyâi't-Türas, 1410/1990), 6/ 13-17; Sedat Baran, "Molla Sadrâ'da Vâcibü'l-Vücûd'un İspatında Burhan-1 Siddıkîn”, Diyanet İlmî Dergi 56 (2020), 218. 
Hüseyin Atay'a göre İbn Sînâ’nın varlık delili zorunlu varlı̆̆ın mahiyeti ve inniyeti üzerine kurulmuştur. İbn Sînâ varlı̆̆1 Tanrı'nın kendisi olarak kabul eder. Yani varlık Tanrı'nın bir sıfatı değildir. Zorunluluk yine varlığa bağlıdır. Yoksa zorunluluk ve varlık iki ayrı şey olarak onda buluşmaz. Varlığı olmaksızın Tanr1'yı ve zorunluluğu düşünmek mümkün olsa da bu zihinsel bir yanılgıdır. Gerçekte varlığ1 Tanrı dışında var kılmak imkânsızdır. ${ }^{57}$ Ezan, Sıddıkîn burhanının bir tür ifadesidir. Çünkü ezanda Tanrı'nın varlığına şahit olma söz konusudur. ${ }^{58}$

Ali Ebrahımzadeh'e göre Sıddıkîn kanıtı varlığı zorunlu mümkün varlık ayrımı üzerinden tahlil eder. Zihnin ve dış dünyada olanın varlık ortak paydasında birleştiği uyarısında bulunur. Bu kanıt, Limmî burhana benzer ancak ondan farklıdır. Çünkü Sıddıkîn kanıtı varlığa ve varlığın apriori bilgisine dayanır. Varlık zorunlu ve tek olmalıdır. Diğer mevcutlar, Zorunlu Varlık'ın sıfat ve fiilleridir. Bir şeyin zâtı ispatlandıktan sonra ancak onun hangi sıfatları ve fiilleri taşıdığı açıklanabilir. ${ }^{59}$

Kısaca, Aristoteles metafizikçi olarak Tanrı'yı metafiziğin konuları içerisinde görmekle birlikte Tanrı kanıtlamasında bir tabiat filozofu gibi hareket etmiştir. Kelâmclar ise eserden müessire giden kozmolojik kanıtlarında Tanrı'nın birliğini ortaya koyabilmek için Temânu gibi delillere yönelmek zorunluluğu hissetmişlerdir. Hâlbuki Sıddıkîn delili, Tanrı'nın varlı̆̆ı yanında birliğini de en açık biçimde ortaya koyabilmiştir. $^{60}$

\section{SONUÇ}

İbn Sînâ'nın İsââât ta tesis ettiği Tanrı kanıtlaması bütün ispatlardan farklı ve metafizik temelli bir ispattır. Bu ispat varlı̆̆ın dış

57 Hüseyin Atay, “İbn Sînâ'da Varlık Delili”, Uluslar Arası İbn Sînâ Sempozyumu, ed. Mehmet Mazak - Nevzat Özkaya (İstanbul: İstanbul Büyükşehir Belediyesi Kültür A. Ş. Yayınları, 2008), 1/303-304.

58 Atay, "İbn Sînâ'da Varlık Delili”, 1/289.

59 Ali Ebrahımzadeh, İbn Sina'da Sıddîkîn Kanıtı: Din Felsefesi Açısından Bir Değerlendirme (Ankara: Ankara Üniversitesi, Sosyal Bilimler Enstitüsü, Doktora Tezi, 2014), 73 79 .

60 İbn Sînâ, el-işâarât ve'n-tenbîhât mea şerhi Nașîruddin et-Tûsî, nşr. Süleyman Dünya (Kahire: Dâru'l-Meârif, 1985), 3/54-55; Engin Erdem, Varlıtan Tanriya İbn Sînânın Metafizì Delili (İstanbul: Endülüs Yayınları, ts.), 315. 
dünyadaki apaçık gerçekliğine ve bunun bir yansıması olarak zihindeki apriori ve bedîhi karakterine dayanmaktadır. Bu iki durum Zorunlu Varlık düşüncesini ortaya çıkarır. Burada unutulmaması gereken şey İbn Sînâ'da Zorunlu Varlık ile Tanrı kanıtlamasının aynı olmadığıdır. Zaten metafizik, bu iki kanıtlama biçiminin ayrımına varılabilmesi halinde mümkün olmaktadır. Şu halde geçerli bir Tanrı kanıtlaması varlık kanıtlamasına bağlıdır. İşte Sıddıkîn delili de bunu ifade etmektedir.

Konu ile yapılan çalşmalarda bahsedilen bu ayrımın görül(e)memesi nedeniyle Sıddıkîn delilinin ontolojik delil ile karıştırıldığı görülmektedir. Sıddıkîn kanıtı varlığın kendisinden hareketle teşkil edilirken ontolojik delil ise varlık kavramından hareketle oluşturulur. Ayrıca yapılan bazı çalışmalarda "zorunluluğun varlığın sebebi olduğu" söylenmektedir. Bunun doğru olmadığını düşünmekteyiz. Özetle İbn Sînâ'nın bu delili zihinsel temelli bir kanıt değil ontolojik sezgi temelli bir kanıttır. Dolayısıyla varlığın sezgisine ve bilgisine eremeyen kimselere delilin söyleyeceği fazla bir şey yoktur.

Ateistler Tanırı'nın varllğının ispatından bahsederken genelde ispattan ziyade Tanrı'nın kendisinin önlerine getirilmesini veya O'nu tecrübe etmeyi/görmeyi isterler. Aslında istekleri makuldür ancak bunu kişileştirilmiş ve bir mahiyete bürünmüş Tanrı üzerinden yapmak isterler. $\mathrm{Bu}$ durumda çoğunlukla aradıkları ve istedikleri şeyi bulamazlar çünkü nesnel âlemde mahiyete bürünmüş Tanrı/Tanrı'lar değil tek ve eşsiz olan Tanrı'nın varlığından başka bir şey yoktur. Şu hâlde onlar Tanrı'nın mahiyeti olmadığından isteklerini elde edememektedirler. Öyleyse varlı̆̆1 yönünden Tanrı'nın inkârının her zaman bir tür mahiyet inkârı olduğunu unutmamak gerekir. Varlığın birliği ve bütün mevcutların varlıkları yönünden Zorunlu Varlık’a bağlı olduğu gibi mahiyeti yönünden de bütün mahiyetler Tanrısal tezahürün bir parçasıdır. Ateistler mahiyet sahibi Tanrı tasavvurlarını inkâr ederken agnostikler bu tasavvurun oluşturulabilecek bir tasavvur olmadığını düşünür. $\mathrm{Bu}$, mümkün birer tutum olmakla birlikte her iki tutumun hatası evrendeki bütün ontolojik durumların Tanrı'ya bağlı durumlar olduğunu görememeleridir. Başka bir ifadeyle ateist, agnostik ve sofistlerin metafiziksel anlamda varlığın bilgisine sahip olmadığı ve bu yüzden kendi öz varlıklarının bile farkında olmadıkları söylenmelidir. Panteizm de dâhil olmak üzere bunun gibi tavır alışlar; ilke ile zuhur, varlık ile varoluş ve neden ile sonuç arasındaki seviye farkını ortaya koyan metafiziği bilmemekten kaynaklanır. 
Bütün metafizik, varlığın apriori idrakine dayanır. Varlığın apriori idraki ile bu idrakin farkında olmak başka şeylerdir. Aynı şey Tanrı fikri için söylenince ortaya Sıddıkîn delili çıkar. Yani apriori varlık fikri Tanrı fikrini de içine alır ancak zihinsel anlamda Tanrı fikri apriori değildir. Böyle olmadığının en açık delili ateist, agnostik vb. gibi inkârcı gruplardır.

Halklar Tanrı'nın varlığına şahittir. Vehim gücünün sadece bireysel işlevinin olmadığını bu gücün aynı zamanda toplumsal bir yansımasının olduğu ileri sürülebilir. Vehim gücü sayesinde insanlar somut dünyayla soyut dünya arasında ilgi ve bağlantı kurmaktadır. Bu sebeple halklar Tanr1 inancinı sıkıca benimsemekte ancak mahiyeti yönünden Tanrı'yı pek kavrayamamaktadır. Şu halde halkın zihinsel açıdan içine düştüğü şaşkınlı̆̆ın ve yetersizliğin telafisi olarak peygamberin ve filozofun/arifin önderliğine ihtiyaç duyduğu, onların varlıklarının Tanrı'nın varlığının bir tecellisi olduğu ve bunlara sıddıklar denildiği iddia edilebilir.

Sıddıkların hükmü varlık merkezli bir kanıtlamadır. Bu kanıt bağlamında ortaya çıkan zorluk, varlı̆̆ın kaplam olarak Tanrı'dan daha geniş olup olmadığıdır. İkinci zorluk ise Tanrı'nın varlığının evrenin varlığından daha büyük ve mükemmel olduğunun söylenmesidir. Bu durumda iki ayrı ve paralel varlık sahası ortaya çımaktadır. Nesneden özneye giden ispat yöntemlerinde de aynı durum söz konusudur. Bunun için şu çözümü teklif edebiliriz: Ezanda Allah-u ekber denilip Allah-u ekmel denilmemesinin olası sebebi bir mevcudun bütün mevcutları kuşatamamasina rağmen kendinde bütün yetkinliği toplayabilir olmasındandır. Mesela insan, kâinatın küçük bir özeti olarak kemale erebilir ancak görünür büyüklüğü açısından kâinatın çok küçük bir parçasıdır. İşte bu yüzden bütün varlığ1 kuşatıcı olmak niteliği bütün kemalin en birincil niteliği olarak dile getirilmiştir. Şu hâlde en mükemmel olanın öncelikle en büyük olması gerekir ki o da varlığın bütünüdür. Bu açıdan Anselm'in varlık delilini Allah-u Ekber'in karşıllğ̆1 olarak görmek pek isabetli gözükmemektedir. Doğrusu Allah-u Ekber'in varlığın teşkîkî niteliğinin bir karşıllı̆ı olmasıdır. Çünkü teşkîk niteliği dikkate alınmaksızın Allah'ın diğer varlıklara göre konumlandırılması doğru değildir. 


\section{KAYNAKÇA}

Abdullah Faruq - A. Johnson, Steven. "İbn Sina Metafiziğinde Dördüncü Ontolojik Delil”. çev. Zeynep Baktemur. Din Felsefesi Açısından Meşsââ Gelen-Ek-i IV. ed. Recep Alpyağgl. 429-438. İstanbul: İz Yayıncilik, 2019.

Alper, Ömer Mahir. “İbn Sînâ'da Tanrı'nın Kanıtlanması Sorunu: O Gerçekten Kelâmcılardan Etkilendi mi?”. İstanbul Üniversitesi İlabiyat Fakültesi Dergisi 7 (2003), 61-77.

Atay, Hüseyin. "İbn Sînầda Varlık Delili”. Uluslar Arası İbn Sînâ Sempozyumu. ed. Mehmet Mazak - Nevzat Özkaya. 1/281-306. İstanbul: İstanbul Büyükşehir Belediyesi Kültür A. Ş. Yayınları, 2008.

Baran, Sedat. "Molla Sadrâ'da Vâcibü'l-Vücûd'un İspatında Burhan-1 S1ddıkîn”, Diyanet İlmî Dergi 56/1 (2020), 205-224.

Bozkurt, Ömer. "İbn Sînâ’nın Tanrı Anlayışının Dayandığı Temel İlkeler". Diyanet İlmî Dergi 50/1 (2014), 67-86.

Cihan, Ahmet Kamil. İbn Sina ve Gazali'de Bilgi Problemi. İstanbul: İnsan Yayınlar1, 1998.

Dağ, Mehmet. "Ontolojik Delil ve Ç1kmazları". Ankara Üniversitesi Ilâhiyat Fakültesi Dergisi 23 (1979), 287-318.

De Haan, Daniel D. “İbn Sina, Tanrı'nın Varlığını Nerede İspatlıyor?”. çev. Sultan Turan. Din Felsefesi Aģısindan Meşşầ Gelen-Ek-i IV. ed. Recep Alpyağı1. 453-470. İstanbul: İz Yayıncılık, 2019.

Demirkol, Murat. Tûsı̀nin İbn Sina Savunması. Ankara: Fecr Yayınları, 2010.

Descartes. Felsefenin İlkeleri. çev. Mesut Akın. İstanbul: Say Yayınları, 1995.

Ebrahimzadeh, Ali. İbn Sina'da Sıddîkîn Kantt: Din Felsefesi Açısından Bir Değerlendirme. Ankara: Ankara Üniversitesi, Sosyal Bilimler Enstitüsü, Doktora Tezi, 2014.

Ebrahimzadeh, Ali. “İbn Sînâ'da Zorunlu Varlı̆̆ın Mahiyeti Meselesi”. Dini Araştormalar 15/41 (2012), 156-162. 
Erdem, Engin. Varlıktan Tanriya İbn Sinânnn Metafiziłe Delili. İstanbul: Endülüs Yayınları, ts.

Guénon, René. Doğu Düşüncesi. çev. Lütfi Fevzi Topaçoğlu. İstanbul: İz Yayıncilık, 2. Bask1, 2004.

Hick, John. “Tanrı'nın Varllğının Delilleri”. çev. Şahin Efil. İnönü Üniversitesi Uluslararasi Sosyal Bilimler Dergisi 2/2 (2013), 77-94.

İbnü'l-Arabî. Fusûsü'l-Hikem. çev. Nuri Gencosman. İstanbul: MEB Yayınları, 1992.

İbnü’l-Arabî. Fütûhât-ı Mekkìyye. çev. Ekrem Demirli. 18 Cilt. İstanbul: Litera Yayınc1lik, 2006-2013.

İbn Sînâ. Arş Risalesi. çev. Enver Uysal. Uludağ Üniversitesi İlahiyat Fakültesi Dergisi 9/9 (2000), 641-655.

İbn Sînâ. Dânişnâme-i Alẩ. çev. Murat Demirkol. İstanbul: Türkiye Yazma Eserler Kurumu Başkanlığ1 Yayınları, 2013.

İbn Sînâ. İhlâs Sûresi Tefsiri. çev. Ahmet Hamdi Akseki. haz. Ahmet Faruk Güney. Ankara: Diyanet İşleri Başkanlı̆̆ı Yayınları, 3. Basım. 2019.

İbn Sînâ. el-İsârât ve'n-tenbîhât mea şerhịi Nașîruddin et-Tûsî. nşr. Süleyman Dünya. 4 Cilt. Kahire: Dâru'l-Meârif, 1985.

İbn Sînâ. İsaretler ve Tembibler. çev. Ali Durusoy - Ekrem Demirli. İstanbul: Türkiye Yazma Eserler Kurumu Başkanlığı 2014.

İbn Sînâ. Analitikler. çev. Ömer Türker. İstanbul: Litera Yayıncılık, 2014.

İbn Sînâ. el-Mebde've'l-me'ad. Tahran: İntişârât, 1998.

İbn Sînâ. Metafirịk. çev. Ekrem Demirli - Ömer Türker. 2 Cilt. İstanbul: Litera Yayınclik, 2013.

İbn Sînâ. el-Mübâhasât, thk. Muhsin Bidarfer. Tahran: Müessese-i Pejûheşha-yı Hikmet ve Felsefe-i İran, 1396.

İbn Sînâ. et-Ta likâat. nşr. Abdurrahman Bedevî. Beyrut: Dârü'l-İslâmiyye, ts.

Kur'ân-ı Kerîm Meâli. çev. Halil Altuntaş-Muzaffer Şahin. Ankara: Diyanet İşleri Başkanlığ Yayınları, 2010. 
Kutluer, İlhan. İbn Sina Ontolojisinde Zorunlu Varlk. İstanbul: İz Yayincilik, 2013.

Mayer, Toby. "İbn Sîn'nın 'Burhânu's-Sıddıkîn'i”. çev. Temel Yeşilyurt. İnönü Üniversitesi İlabiyat Fakültesi Dergisi 8 (2003), 255-276.

Molla Sadrâ. el-Hikemetül-mütéáliye fì esfâri'l-erba'a. 9 Cilt. Beyrut: Dâru İhyâi't-Türas, 4. Bask1, 1410/1990.

Morewedge, Parviz. "İbn Sina, N. Malcom ve Ontolojik Delil”. çev. Mehmet Ata Az. Din Felsefesi Açısından Mesşẩ Gelen-Ek-i IV. ed. Recep Alpyağıl. 394-403. İstanbul: İz Yayıncılık, 2019.

Morewedge, Parviz. "İbn Sina Metafiziğinde Ontolojik Argümanın Üçüncü Versiyonu". çev. Yasin Ramazan Başaran. Din Felsefesi Açısından Meşşầ Gelen-Ek-i IV. ed. Recep Alpyağıl. 404-428. İstanbul: İz Yayıncilık, 2019.

Özden, H. Ömer. “İbn-i Sina ve Descartes’in Varlık Anlayışları Bakımından Karşılaştırılması". Felsefe Dünyası 16 (1995), 75-83.

er-Râzî, Fahreddin. Şerhü̈l-İsârât ve't-tenbîhât: felsefe, tabïyyat, ilahiyyat ve irfan. thk. Ali Rıza Necefzade. 2 Cilt. Tahran: Encümen-i Asar ve Mefahir-i Ferhengi, 2005/1384.

Râzî, Kutbüddin. Şerhü̉l-işârât vet-tenbihât. Kum: Neşrü'l-Belâga, 1435.

Reçber, Mehmet Sait. “Tanrı'nın Varlığının Delilleri”. Din Felsefesi, ed. Recep Kılıç - Mehmet Sait Reçber. Ankara: Grafiker Yayınları, 2014.

Schuon, Frithjof. İslâm ve Eželî Hikmet. çev. Şahabeddin Yalçın. İstanbul: İz Yayınclik, 1998.

Tolstoy. İtiraflarm. çev. Orhan Yetkin. İstanbul: Kaknüs Yayınları, 1999.

Yezdî, Muhammed Tâkî Misbâh. el-Menhecü'l-cedîd fi ta'limi'l-felsefe. nşr. Muhammed Abdü'l Münim el-Hakanî. Beyrut: Dârü’t Teârifi li'lMatbûât, 2008. 